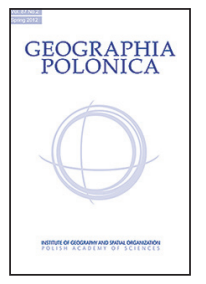 \\ INSTITUTE OF GEOGRAPHY AND SPATIAL ORGANIZATION \\ POLISH ACADEMY OF SCIENCES \\ www.igipz.pan.pl \\ www.geographiapolonica.pl
}

\title{
TWENTY-FIVE YEARS OF HUMANISING POST-SOCIALIST HOUSING ESTATES: FROM QUANTITATIVE NEEDS TO QUALITATIVE REQUIREMENTS
}

\author{
Petr Šimáček ${ }^{1}$ • Zdeněk Szczyrba ${ }^{2}$ • Ivan Andráško ${ }^{1}$ • Josef Kunc ${ }^{3}$ \\ ${ }^{1}$ Department of Geography \\ Masaryk University \\ Kotlářská 2, 61137 Brno: Czech Republic \\ e-mails: petr.simacek@upol.cz・geoganry@mail.muni.cz \\ ${ }^{2}$ Department of Geography \\ Palacký University Olomouc \\ 17. listopadu 12, 77146 Olomouc: Czech Republic \\ e-mail: zdenek.szczyrba@upol.cz \\ ${ }^{3}$ Department of Regional Economics and Administration \\ Masaryk University \\ Lipová 507/41a, 60200 Brno: Czech Republic \\ e-mail: kunc@econ.muni.cz
}

\begin{abstract}
After the fall of the Iron Curtain, CEE cities (as well as other cities in the former Socialist Bloc) experienced dynamic development in many areas. The presented article deals with one of the key areas of the post-socialist transformation of the city, specifically the humanisation of mass housing in large housing estates. These housing estates from the central planning period still dominate the skyline of many CEE towns. At the beginning of the 1990s, housing estates suffered from a number of shortcomings that needed to be put right within the frame of their humanisation. The paper analyses a more than two decade-long process of housing estate humanisation which gradually led to the replacement of the monofunctional (strictly residential) model with a multifunctional model. This leads to improvement of civic amenities, implementation of new urban-architectural solutions and the creation of new job opportunities. As a result, these changes increase the quality of life in housing estates, both from an objective and subjective point of view. Changes in the spatial, social, economic and physical structure of housing estates after 1989 will be analysed using examples from hierarchically different locations in the Czech Republic. The synthesis of findings will be supplemented with the results of empirical studies that were carried out by geographers, sociologists and urban planners.
\end{abstract}

\section{Key words}

humanisation processes - postsocialistic housing estates - postsocialistic transformation $\cdot$ Central and Eastern Europe 


\section{Introduction}

Housing estates, especially those built using the large-panel system technology in the twentieth century, represent a noticeable and characteristic element in the physiognomy of many European cities. Housing estates were built in Western as well as Central and Eastern Europe (hereinafter referred to as CEE), and their construction aimed at fulfilling the social programmes of providing housing to millions of Europeans, in particular after World War II, which had caused tremendous damage to housing and infrastructure (Hamilton et al. 2005; van Kempen et al. 2005). The essential feature in the development of housing estates was the accumulation of large housing structures in urban residential zones dedicated to this purpose (primarily on the outskirts of cities). The basic objective of furnishing the necessary quantity of flats over a certain period of time was planned centrally in CEE countries as well as in most democratic countries, for instance, Sweden (Hall \& Vidén 2005), Germany (Wiegandt 2000; Rietdorf et al. 2001) and France (Coudroy de Lille 2001).

In contrast to housing estates in Western European countries, the socialist housing estates were specific in some regards, caused by the different social principles of their development. In a period of the centrally planned economy, the housing stock in housing estates was intended for broad masses of people irrespective of their social and economic status. Housing estates were places of permanent social contact inside the local population. Thus, housing estates played one of the key roles in the socialisation of society. The growing socialist urbanisation triggered by industrialisation effects (housing estates as a direct effect of development of industrial plants) and the increased intensity of construction of the housing estates brought considerable improvement in sanitary and other housing conditions analogous to housing estate development in Western Europe (Murie et al. 2003). A different aspect of socialist housing estates was the fundamental discrepancy between the offer and the real demand, which was manifested in the evasion of the flat allotment system with elements of ubiquitous corruption (Jarosz 2010).

Development after the fall of the Iron Curtain brought new challenges to the housing estates built during the socialist era. The extent of problems the socialist housing estates begin to face was proportionate to their shortcomings from the previous era, like the poor quality of urban and architectural design, high energy losses caused by the panel technology used, and the frequent absence of suitable civic amenities. The problems of the physical environment were accompanied by the negative effects of social deprivation, which in some places resembles the poverty and social exclusion trap (Wassenberg 2004). Moreover, the number of citizens living in housing estates in post-socialist countries is several times higher in comparison with Western Europe. The issues of the revitalisation and humanisation of the housing estates represents a social problem with greater relevance in these countries than elsewhere (Dekker et al. 2005). It can be stated that the post-socialist housing estates have not yet come to the phase of so-called stigmatisation applied to numerous housing estates in Western Europe (Waseenberg 2004), although some housing estates (especially the large ones) have begun to lose their social cohesion and are becoming more dangerous.

Save for some exceptions (several cities in the eastern part of Germany, e.g. Schütte $\&$ Kühn 2004), the housing estates of CEE countries have begun more or less successful revitalisation and humanisation. Tools applied in these processes focus primarily on remedying earlier shortcomings (see above) and modernising the physical environment of the housing estates. There are also parallel programmes aimed at reducing their social deprivation and the exclusion of selected groups of population. This way, considerable financial resources have been invested with a view toward increasing the quality of life of people 
living in the post-socialistic housing estates, frequently with contributions from the Structural Funds of the European Union.

Our paper focuses on three key problems:

1. The historic context of housing estate development in CEE;

2. The humanisation of the housing estates;

3. The perception of the housing environment by the housing estate residents in the post-socialistic stage of their development.

Using this pragmatic layout, we intend to show readers the causality of development of the socialist housing estates, the processes of their humanisation as a multi-disciplinary approach to the regeneration of this part of the CEE urban space, and, finally, the perception of the housing estates by their residents, which reflects both the present and the future of the post-socialist housing estates. The authors hope that despite the partial concentration on the Czech Republic, the conclusions presented in this paper are generally true and allow deeper insight into the issues of the humanisation of the post-socialist housing estates in CEE twenty-five years after the fall of the Iron Curtain.

\section{Theoretical introduction in the issues of housing estates}

The history of the construction of panel houses began in the Netherlands and Germany in the early 1920s. A number of relatively unique 'housing estates' were built in the interwar period (Germany, France, Scandinavian countries), mostly of a solitary nature, not in the form of the present-day large housing blocks. The architectural design was also different, with a combination of panels and a dominant reinforced-concrete structure (Fetters 2002; van Kempen et al. 2005). The ideological principles of the construction of panel housing estates therefore date back to the avant-garde, functionalist architectural theories of the 1920s and 1930s, formulated in the urban planning document called the "Athens Charter". The principles are based on the noble theory of providing dignified, hygienic and economically and environmentally acceptable accommodation to all people who live in the permanently expanding cities. The architects had no previous experience with building development of this type and therefore had to base their conceptions on theoretical hypotheses which were often very utopian. Various partial solutions appeared as very attractive and desirable at first, but practical applications soon showed that certain problems were removed only to be replaced by new issues (Musil 1985; van Kempen et al. 2005).

After World War II, most European countries embraced a concept for a stateorganised solution to the housing shortage compounded by the war damage to the housing stock and the 'traditional' demographic reaction of the young population - the babyboom. As already stated, the new housing estates shared the architectural and planning conceptions inspired by the interwar avantgarde, i.e. free street layouts, separated functional zones, and tower buildings. Whereas Western-European countries saw the housing estates (especially the panel ones) as a shortterm experiment, although not insignificant, panel houses were a dominant and often exclusive form for the development of new flats in apartment houses in the CEE countries beginning in the late 1950s (Rowlands et al. 2009; Špaček 2012).

Housing estates were being built in open spaces on the outskirts of post-war CEE cities. The reasons behind the construction of largearea residential complexes can be found, in particular, in so-called socialist industrialisation, which took place in most of the countries mentioned above with various levels of intensity. The construction of new industrial plants brought a high influx of people to the cities, and it was necessary to provide housing to incoming workers. This problem was to be solved by the multi-storey apartment houses. Moreover, the similar appearance of the buildings corresponded to the communist ideology of the equality of all people (Danielová 2012).

The historical context of the conception and construction of housing estates can 
be easily divided into to the individual decades and their typical attributes. The late 1940 s, i.e. the period of transition to socialism in CEE countries, were characterised by the efforts of city planners and architects to locate the projects in the city centres and residential sectors. It soon became obvious, however, that the regeneration of pre-war urbanised areas could not meet the needs of the post-war housing shortage (Kallabová 2004). In Berlin alone, $70 \%$ of buildings were destroyed during the war, while it is estimated that up to $85 \%$ of urbanised areas were decimated in Warsaw (Hamilton 2005).

The following era of the 1950s was marked by confusion in the conception of housing development, stereotyped urban planning and unrealistic expectations for the future. New housing complexes were planned and built on open spaces on city outskirts (Hrůza 1996; Berey 1997). Despite some technical drawbacks (e.g. the absence of central heating), the first post-war housing estates are rated better in hindsight than the ones built in later periods. In some cases, the original concept of pre-war 'garden cities' was reflected in the housing environment conception in the form of the block sizes, building height, spatial arrangement, amount of green spaces, overall design, as well as materials used (bricks) (Kallabová 2004; Kallabová \& Bílek 2006; Špaček 2012).

In many countries, the first generation of socialist housing estates was constructed primarily in mining regions, and their architectural design followed Soviet examples (Špaček 2012). Called 'socialist realism', this style was developed and utilised in the Soviet Union beginning in the 1930s, and it aggravated living conditions and the housing culture, including aesthetic standards. The defining characteristics of this development were self-contained blocks of houses that created a rectangular road system and pseudo-courtyards separated from public traffic. The urban form was dominated by stereotypes based on Soviet satellite towns, but the overall building aspect produces an effect of semi-open areas, which seems to be relatively pragmatic and successful from today's perspective. In addition to the housing function, the housing estates still had to fulfil an aesthetic function, allowing the residents to develop certain relationships with the environment and providing orientation by means of landmarks (large columns, ornamental portals, imitation of battlements, etc.). The placement of civic amenities (especially shops and services) in the residential building ground floors was of extraordinary value (Kallabová 2004).

The 1960s brought a quantitative advance in housing estate construction with the introduction of precast panels that replaced the original bricks. The introduction of panels meant an unprecedented acceleration of construction, making the whole building process more efficient and bringing substantial changes to the building technology (Rojík 1974). The method of construction of housing estates fully corresponded to social housing, which was, however, intended for the vast majority of population (in contrast to Western European countries). Housing estates were built outside green fields outside city centres, a result of the effort to overcome the shortcomings of spontaneous development of housing estates without comprehensive amenities. Western European examples of urban projects (garden suburbs) were mostly abandoned, and the social infrastructure and green spaces were incorporated in the housing estates many years after the flats were finished (often in an extent that did not meet the needs). Following the example of Soviet cities, multi-storey buildings and substantially larger residential districts were preferred (Kallabová 2004), and housing development was primarily aimed at large cities with acute housing shortages (Berey 1997; Musil 2002; Halás \& Džupinová 2007). Civic amenities on the residential building ground floors gradually disappeared, giving way to so-called monofunctional civic infrastructure buildings. The rate of building development gradually accelerated, while positive elements as well as unique features faded out at the expense of growing uniformity, monotony and density (Kallabová, 2002). 
The subsequent 1970s and 1980s represent the peak period in the construction of housing estates in CEE countries, during which the majority of panel houses were built (Musil 2002). Housing complexes of this time had even more serious shortcomings than those built in the previous periods - a growing domination of panel houses, their chaotic arrangement in the environment, unsuitable and insufficient placement of civic amenities - frequently combined with complicated connections to the inner city (Kallabová 2004). The 1980s also saw increasing general criticism by both experts and the public. In contrast to reservations from the previous periods mostly related to individual problems (flat size standards, the absence of civic amenities, unkept greenery, etc.), the housing estates began to be perceived as basically inadequate and poor housing constructed on the lowest possible quality level.

The regime change in the vast majority of the CEE countries in the late 1980s and early 1990s was a milestone in the construction of panel housing estates. Housing estates became "the embodiment of everything people wanted to change - they were grey, uniform, inhumanly grandiose" (Maier 2003: 654). This type of building development was suppressed or completely terminated in the 1990s. A significant difference between the 'west' and the 'east' of post-Soviet Europe is apparent in this context. Whereas a number of housing estates in the former German Democratic Republic were abandoned and demolished over the last two decades, something similar was and still is impossible in Central European countries due to the housing shortage and economic situation, while housing estate development still continued in Eastern Europe, albeit at a slower rate (Leibmann \& Rietdorf 2001; Kallabová 2004; Hamilton et al. 2005).

At present, large housing complexes built using large-panel system technology constitute a significant part of the urban structure of cities in the post-socialist countries and has become its typical feature. For the sake of comparison: the ratio of the population living in housing estates in the former EU 15 countries does not exceed 10\%, while in CEE countries ${ }^{1}$ (Murie et al. 2003) 20-35\% (up to $45 \%$ according to other sources) of the population lives in 11-14 million flats (Mládek 2000; Liebmann \& Rietdorf 2001; Kallabová 2002). Panel apartment houses are concentrated in housing estates, and approximately 35 million citizens (30\%) from the above number live in housing estates with more than 2,500 flats, which corresponds to more than 11 million flats, the majority of housing built between 1960 and 1990 (Müller 1997; Kallabová 2004). The ratio of flats in housing estates in the overall housing stock and housing development during 19601990 in selected CEE countries is shown in Figure 1.

Radical changes in society after 1989 (see more in Stryjakiewicz 2009; Jordan 2010) resulted in a significant transformation of the position of panel housing estates in CEE countries. Whereas housing estates represented the main method of development of centrally planned socialist cities, the capital and investments, mainly private, in the post-socialist urban environment focused on the dynamically developing suburban areas, attractive parts of the inner cities and the city centres as such. To a certain extent, housing estates stood aside from the most striking changes in the transforming cities (Stanilov 2007; Sýkora 2009; Špaček 2012). The current situation of panel housing estates in the post-Soviet bloc is considerably different, and this disparity can intensify even more in the future (Temelová et al. 2011). This is suggested by international experience, indicating clearly that urban-architectural characteristics consolidating housing estates as a type of residential development usually do not represent a sufficient factor that would determine the fate of locations, even within relatively homogeneous conditions of the individual countries (Hamilton 2005; Rowlands et al. 2009). Despite, or maybe due to, this fact, tackling the issues of housing estates, especially their

\footnotetext{
1 Excluding the countries of the former Soviet Union.
} 


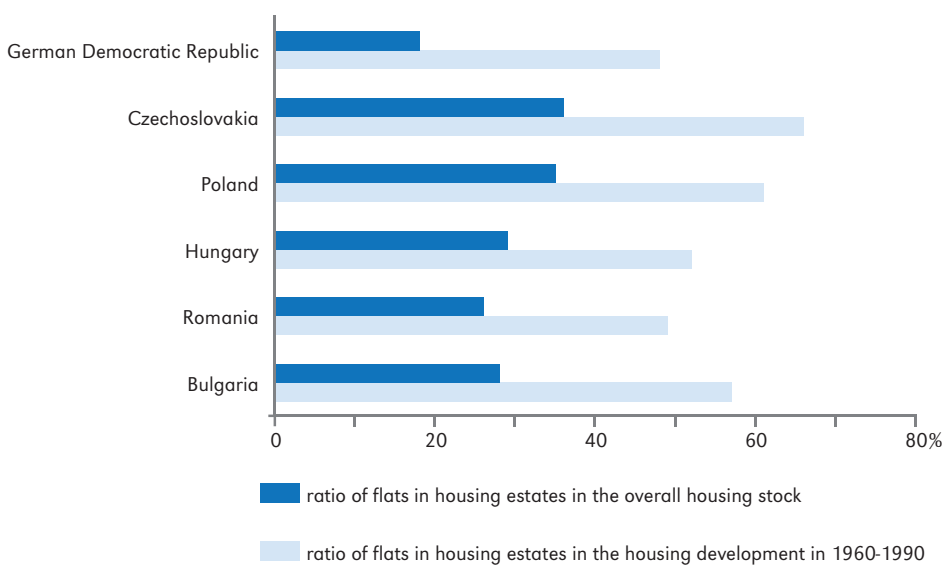

Figure 1. Housing stock in housing estates in the selected CEE countries

Source: Müller (1997)

humanisation, is viewed as one of the main challenges of post-socialist cities (Szelenyi 1996; Musil 2002; Špaček 2012).

\section{Humanisation of post-socialistic housing estates}

According to Kallabová (2004), the humanisation of housing estates is not a new phenomenon. This topic was being debated in the CEE countries well before 1989, but the implementation of humanisation was frequently reduced to landscaping. However, care for the new green spaces was then neglected, leading to the degradation of the environment and complications in the sustainability of these 'humanisation' efforts. The concept of the humanisation of housing estates should be perceived today as a process for the comprehensive improvement of the environment, emphasising the sustainability of these housing complexes. However, the process itself is a long-term one and incorporating a wide spectrum of activities (see Fig. 2), the global objective of which is to improve the condition of the housing estates on the social, economic, technical, and urban-architectural level (Dimitrovska Andrews \& Sendi 2001; Matlovič \& Sedláková 2007; Kovács \& Herfert 2012; Warchalska-Troll 2012; Šuška \& Stasíková 2013).
The meaning behind the concept of the humanisation of housing estates varies depending on whether housing complexes in Western Europe or those in the postsocialist part of Europe are being discussed. In both regions, humanisation means a reaction to the reminiscence of the past, and one can state that the general objective is identical - rectifying the shortcomings of the past and, in doing so, improving the current condition, ideally with an outlook to the near future. The problems are partially analogous (for instance, monofunctionality, the latent threat of concentration of undesirable social phenomena), but whereas Western Europe sees humanisation mainly as the rectification of the social environment emphasising the differentiability of the structure of the housing estate residents, the post-socialist countries perceive it primarily as rehabilitation of the physical environment of housing estates (Tanninen 1994; Lux et al. 2005; Sunega \& Kostelecký 2007; Matlovič \& Sedláková 2007).

As stated above, the need for humanisation was triggered especially by real problems inherent in post-socialist housing estates (and which they still suffer from in many cases). However, these problems are not necessarily uniform as regards their nature and they can vary considerably depending on the size of the municipality, the size of the individual 


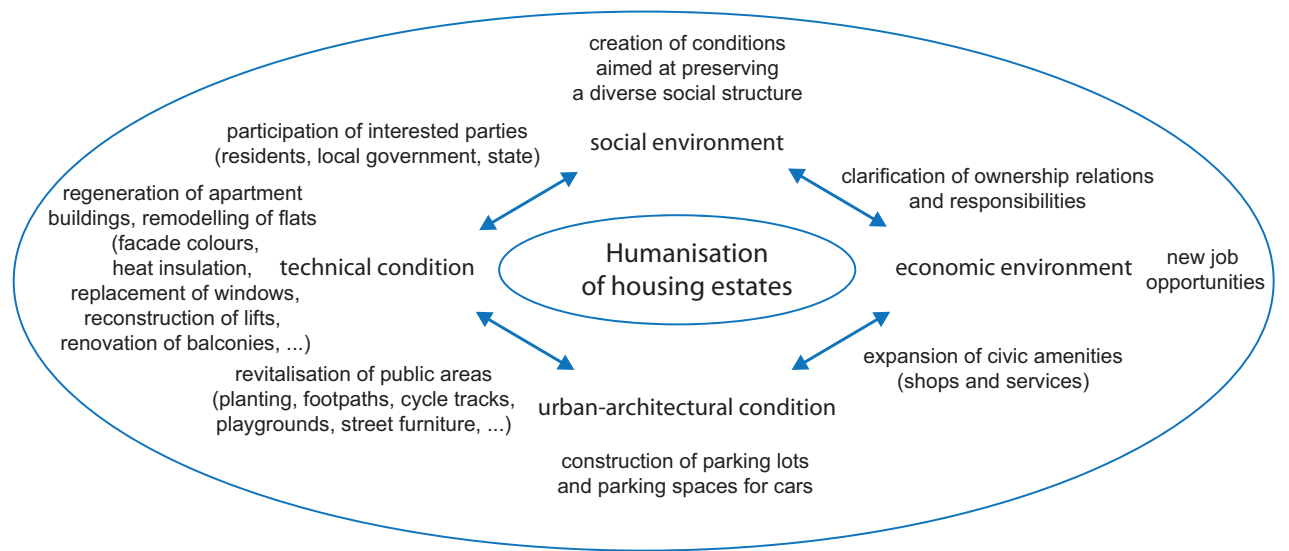

Figure 2. Individual activities participating in the overall process of humanisation of post-socialist housing estates

housing estates, the period of their construction and their location in the urban area. From the viewpoint of the physical environment, humanisation applies primarily to the technical condition of the buildings (and flats inside), the poor condition of public areas, the absence of some civic amenities (residential monofunctionality), unsystematic solutions of motor traffic, and an omnipresent uniformity, resulting in a low urban-architectural value and other issues. Another problem, one associated primarily with the privatisation of elements of the housing stock, was insufficient clarification of ownership relations and the accompanying authority and responsibility for individual locations.

Proper humanisation also requires civic involvement in the decision-making processes aimed at rectifying the housing environment (Abramson 1992; Sunega \& Lux 2004). Although this phenomenon was quite rare after 1990, it has gradually gained momentum, at first very slowly, but with increasing speed after 2000, and has essentially become the standard. It has been shown that an increasing number of residents of these housing complexes want to actively influence the appearance of their housing environment. However, there are various approaches to participation in the decisionmaking sphere, which frequently determines the particular form of humanisation. The degree of participation of local residents is often at the level the local decision-making sphere desires. And yet, the spectrum of participation is very broad - from cases in which citizens are heard out but their opinions are taken into consideration only to the extent the local government sees fit, to cases in which citizens are viewed as equal partners with the right to decide on the future of their housing location (Sunega \& Lux 2004).

Whereas the structure of the residents of the post-socialist housing estates was (and still is) quite diverse, the previous humanising efforts focused mainly on the elimination of shortcomings of a technical and urbanarchitectural nature (Lux et al. 2005; Pásztor \& Péter 2009; Trócsányi \& Orbán 2012; Szabó 2013; Szafrańska 2013, 2014; Warchalska-Troll 2013). In this respect, three areas of interest can be pointed out:

1. Remodelling of flats;

2. Regeneration of apartment houses;

3. Revitalisation of public areas.

Various degrees of participation take effect in the above three areas (see Tab. 1 for details), which must be interpreted in terms of shared responsibility in decision-making, but also in terms of financial participation. While the remodelling of flats concerns the individual residents, whose level of participation is clearly high in this area, the regeneration of the buildings is marked by a decline 
in the activation of the residents, which is the lowest in case of the revitalisation of public areas. But the regeneration of the buildings as well as the revitalisation of public areas fundamentally affects the improvement of the conditions of housing estates.

In addition to physical changes made to the appearance of housing estate buildings and their surroundings, the visible effects of the humanisation of panel housing estates also include the construction of new civic amenities. This is basically an aspect of the revitalisation of public areas resulting in the 'destruction' of the original, predominantly monofunctional nature of panel housing estates and their conversion to multifunctional complexes. This is usually achieved by building new shops in the housing estates (or in their close proximity) or by establishing specialised business premises like a hairdresser's or restaurants.

\section{The humanisation of housing estates in the Czech Republic}

As was the case in other socialist countries, Czechoslovakia also experienced the massive construction of housing estates during the socialist period, especially during the 1970 s and 1980s (Musil 1985; van Kempen et al. 2005; Szafrańska 2013). This building development was implemented (to save time and money) primarily using precast panel technology; quantity dominated over quality, which, understandably, was manifested in the need to humanise the housing estates in the subsequent periods (Lux et al. 2005; Temelová et al. 2011; Szabó 2013).

According to the latest census in 2011 (CZSO 2014), there were almost 66,000 apartment buildings built using large-panel system technology in the Czech Republic. The approximately 1.2 million flats in these buildings housed around 2.7 million persons (ca. $26 \%$ of the Czech population, but as much as $50 \%$ in large cities). Flats built using large-panel system technology constitute $30.6 \%$ of the overall housing stock of apartment buildings in the Czech Republic. The ratio of panel housing estates in the overall number of flats dropped by roughly 10 percent in comparison with the situation in the early 1990s (CZSO 2014), a result of new housing development using traditional, nonpanel technologies (usually development projects in cities, and suburbanisation). But this

Table 1. Most common interventions in the technical and urban-architectural environment within the scope of the humanisation of post-socialist housing estates

\begin{tabular}{|l|l|}
\hline \multicolumn{1}{|c|}{ Process } & \\
\hline $\begin{array}{l}\text { Remodelling } \\
\text { of flats }\end{array}$ & $\begin{array}{l}\text { Remodelling of WC and bathroom } \\
\text { Replacement of windows and entrance doors } \\
\text { Installation of new floors } \\
\text { Changes in the layout of rooms (with respect to structural conditions) }\end{array}$ \\
$\begin{array}{l}\text { Regeneration } \\
\text { of apartment houses } \\
\text { Structural support of poor quality construction } \\
\text { Revitaction of energy demand (replacement of windows, thermal insulation of the building } \\
\text { ef public areas }\end{array}$ & $\begin{array}{l}\text { Installation or redevelopment of lifts } \\
\text { Renovation of common areas (entrance, redecoration, new equipment) } \\
\text { Change of colours of the house facade }\end{array}$ \\
& $\begin{array}{l}\text { Better care of green spaces (care for existing vegetation, new landscaping) } \\
\text { Suitable additions to civic amenities (schools, medical facilities, shops, cultural and sport } \\
\text { facilities, etc.) } \\
\text { Construction of children's playgrounds } \\
\text { Additions to street furniture (benches, signs, lights, etc.) } \\
\text { Modification of footpaths (new surface, improvement of their layout) } \\
\text { Construction of special-purpose paths (bicycle lanes, pedestrian zones) } \\
\text { Construction of parking lots and parking places }\end{array}$ \\
\hline
\end{tabular}


does not change the fact that panel housing estates remain a significant element of the physical and social environment, especially in cities. The Czech government was aware of this fact: its housing policy conception saw high potential in buildings using large-panel system technology, because panel houses can achieve a long service life if their maintenance system is properly set (Lux et al. 2005; Csaba 2006; Zadražilová 2013). Therefore, the government decided to introduce various measures and, in particular, direct subsidies in order to create conditions for panel house regeneration. Most subsidy programmes focus purely on the improvement of the technical condition of the buildings, but some of them also cover the revitalisation of public areas within housing estates.

The individual programmes differ in their focus (for instance, according to the house owner or 'problematic nature' of the location). There are two types of subsidies: direct and indirect. In the case of direct subsidies, the government allocates funds for the implementation of specific projects, while indirect subsidies create favourable conditions, for instance, by reducing interest rates for loans required in order to implement various projects. Other funds (apart from the budgets of local and regional governments) that can be utilised for the humanisation of postsocialist housing estates include Structural Funds of the European Union (for instance, the Integrated Operational Programmes; the JESSICA programme). There are numerous subsidy programmes available in the Czech Republic which can be utilised for the humanisation of panel housing estates. The most common is the Regeneration of Panel Housing Estates programme, coordinated by the Ministry of Regional Development, which focuses on the conversion of the current monofunctional housing estates into polyfunctional residential complexes. This programme is intended for municipalities having panel housing estates with at least 150 flats in total. Visualisation of the spatial distribution of subsidies within this programme is shown in Figure 3.
Other popular programmes include (or included) the Programme of Financial Support for the Repairs of Defects in Panel Buildings (1998-2005), intended primarily for the most urgent repairs of the technical condition of panel houses; the Panel Programme (2002-2015), intended for the modernisation and extension of the service life of the current housing stock; the Green Savings Programme (2009-2020) intended for the reduction of energy demand of the houses; and the Programmes of the European Structural Funds (2007-2015), intended for the revitalisation of public areas and the regeneration of apartment houses in selected problematic housing estates (MRD 2014).

It must be mentioned here that the targeted subsidy policy of the state or local governments cannot fully cure the disconsolate condition of panel housing estates. Kallabová (2004) criticises certain repairs and remodelling works that in some cases did not fulfil quality criteria (although this cannot be compared to the period of the construction of the housing estates), taking effect especially in poorly installed heat insulation or bad weathering of balconies. The overall humanisation of these housing complexes must comprise a wide spectrum of activities (see Fig. 2), and not just the rectification of the technical condition (even if reconstruction on its own is quite effective). Another apparent change was made in the environment of housing estates - the expansion of civic amenities (especially shops and services). This fact meant the usually monofunctional - purely residential - complexes were converted into multifunctional complexes, leading to an increase in the quality of life of residents living in the housing estates (Herfert et al. 2013).

\section{Overview of findings from studies on perception of living environment in post-socialist housing estates}

For many reasons, it is not easy to speak about the perception and study of panel housing estates and their environment 


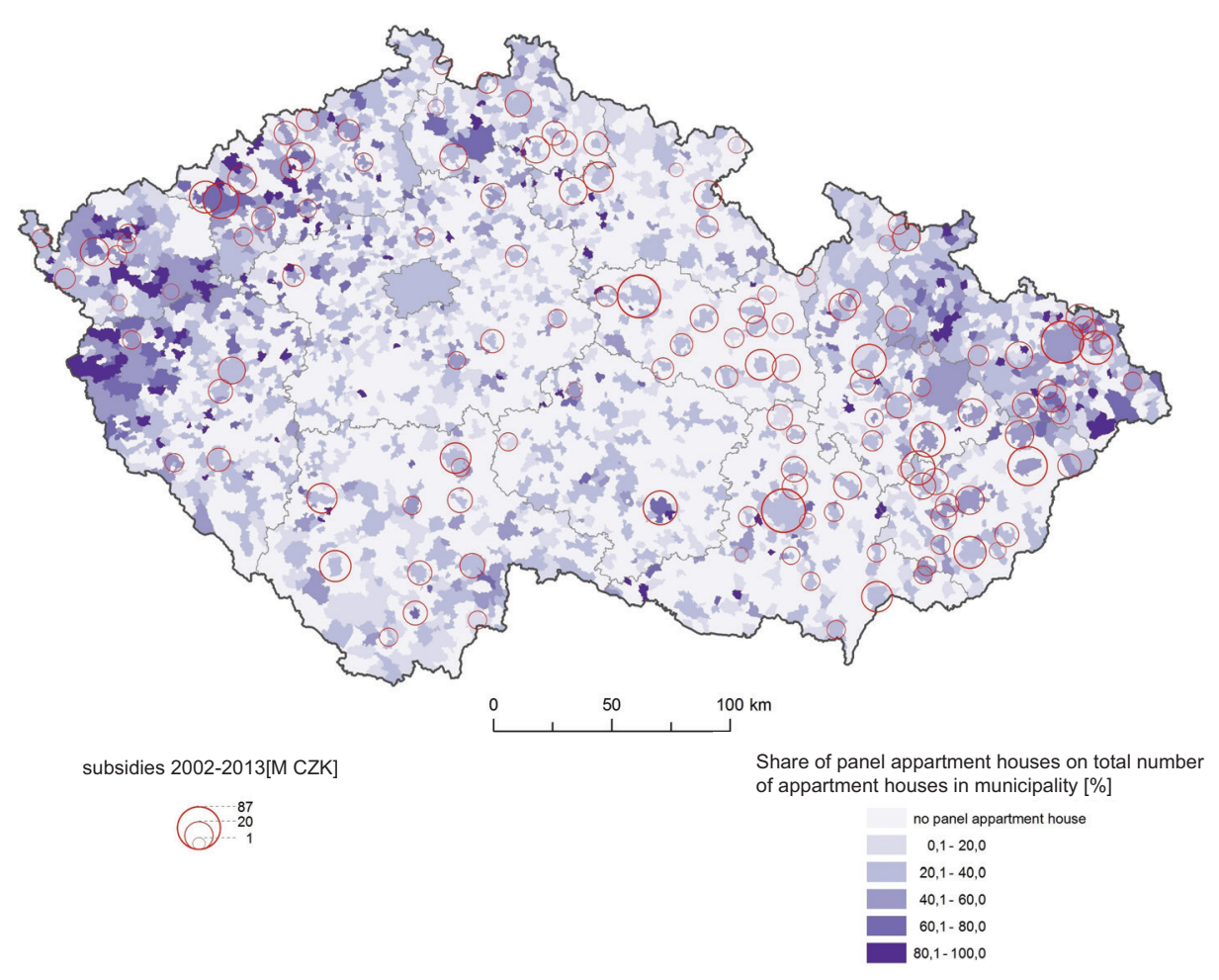

Figure 3. Spatial distribution of projects approved in the Regeneration of Panel Housing Estates programme (for the period of 2002-2013)

Notes: More than CZK 1.7 billion (EUR 61.6 million) was spent from the national budget on the regeneration of panel housing estates from 2002 (start of the programme) until the end of 2013, i.e. CZK 3.9 million (EUR 145,000) per project on average.

Source: based on CZSO 2014; MRD 2014

unambiguously. Housing estates possess some 'typical' attributes (mainly due to the technology of their construction and basic architectural characteristics), but many of them are diversified, for instance, in connection with the countries where the housing estates were built. It is possible to mention the size of housing estates with respect to the area they occupy, the number of their residents, or their social structure. Traditionally, housing estates built in Western Europe are differentiated from those built in so-called post-socialist countries. However, as pointed out by several authors (e.g. Maier 2003, 2005), it is not desirable to generalise even at this level. Each housing estate is unique in one way or another, as it is a specific combination of elements of the living and inanimate environment and their constant interaction. Research on the perception of housing estates can, on one hand, point out many common or 'shared' characteristics and conclusions, but each research also highlights (or should highlight) specific local features that are very important especially from the viewpoint of future development of housing estates (see, for instance, Temelová et al. 2011).

The perception of the environment of housing estates abroad (outside the Czech Republic) has been the subject of numerous studies (e.g. Musterd \& van Kempen et al. 2005; Wiest 2011; Kovács \& 


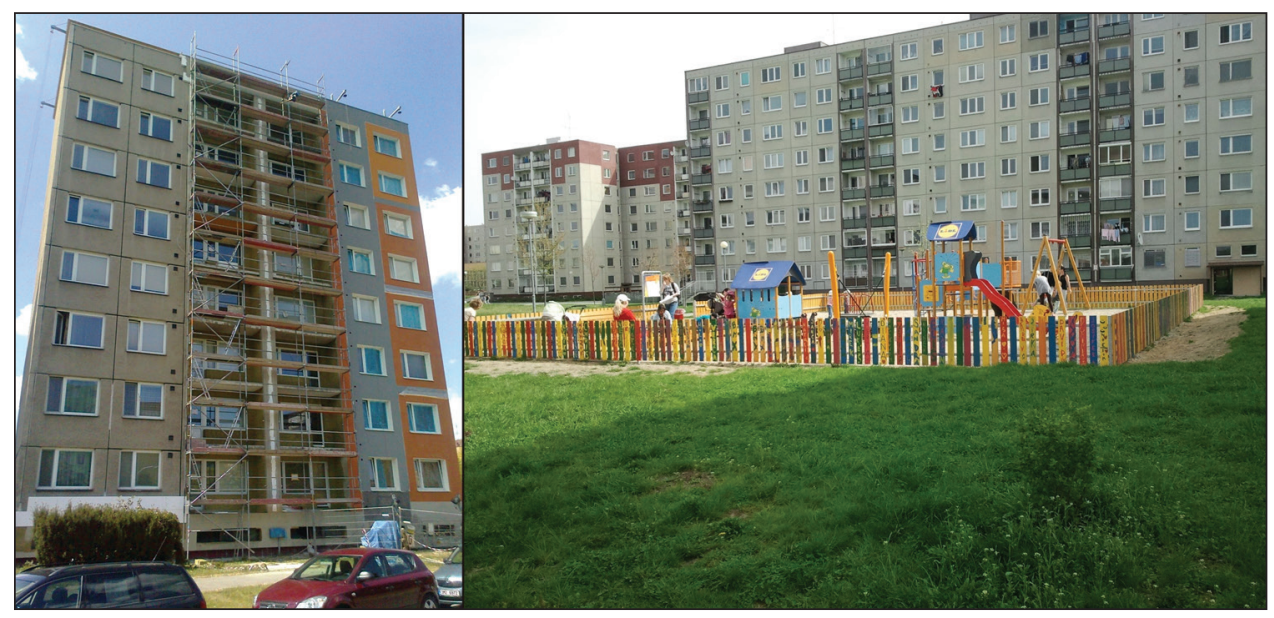

Figure 4. Left - the exterior appearance of the buildings ranks among the most visible aspects of the humanisation of panel housing estates; right - the addition of missing civic amenities is another element in the humanisation of housing estates

Herfert 2012; Warchalska-Troll 2012, 2013; Kabisch \& Grossmann 2013; Kovács \& Herpai 2011 in Szabó 2013; Sargsyan 2013; and others). As regards the territory of the Czech Republic, the studies concerning Slovak housing estates are especially interesting (e.g. Ferenčuhová \& Jayne 2013; Stasíková 2013) - thanks to the existence of the common state of Czechs and Slovaks, virtually identical or at least very similar approaches were utilised in the territory of Czechoslovakia as regards the construction of housing estates or their social composition.

Several studies have addressed housing estates built on the territory of the Czech Republic and their perception. Understandably, the studies differ one from another by the methodologies, approaches and methods used, professional background of their authors, or their priority orientation (as regards the research problem, target group, place of investigation, etc.).

Divina (2010), for instance, pointed out the different perception of the spatial structure of housing estates in Brno using the mental mapping method. Barvíková (2010) examined the perception of Jižní Město (South City) housing estate in Prague through interviews with people who spent their childhood there.
Another frequent tool of inquiry into attitudes towards housing estates is questionnaire survey (e.g. Steinführerová 2003; Andráško et al. 2013; and others).

In terms of research issues, the theme of the 'satisfaction' of residents with their living environment (both physical and social) is very common. This can apply to the surroundings of the houses, but also to the houses and/or flats as such. This orientation of investigation is understandable with respect to the experts' efforts to obtain information relating to the subjective perception of the individual's 'quality of life' - as pointed out by Andráško 2013, the study of satisfaction represents an important direction of research in this respect. Various investigations with this orientation were made in the territory of the Czech Republic beginning in the 1970s (as mentioned by Maier 2003; Kallabová 2004) and their results were often published and discussed afterwards. The key study in this respect is that of Musil 1985, which, for instance, provided information on the positive as well as negative aspects perceived by residents with respect to the environment within housing estates, which were still forming at the time, and how they evaluated the environment. Investigations 
of a similar orientation were also conducted after 1990. Steinführerová (2003) points out a long-term study into the perception of the environment of panel housing estates in Brno (made in 1988 and 1995), followed up recently by a study conducted by AUGUR Consulting (2011). Two fundamental conclusions can be drawn after summarising and simplifying the results of these studies:

1. The residents of housing estates were (and still are) aware that living there is specific to a certain extent, with rather negative results in some cases. As stated by Kallabová (2004: 87), "the negative features of the quality of housing estates, as perceived by the residents, include low aesthetic qualities, architectural ambiguity, monotony, poor design, greyness of masses and faint colours, absence of semi-public areas, poor quality of workmanship, unsightly and unsanitary waste containers. Criticism also applies to the ambiguity of spatial organisation, which causes disorientation". Andráško et al. (2013) points out a typical problem of contemporary housing estates (and other locations) - the lack of parking lots. It is necessary to mention that some of the above 'traditional' shortcomings (like 'greyness' and 'faint colours') are currently being rectified as part of the revitalisation measures at housing estates.

2. The other observation is even more important - it states that despite some negative aspects, the residents are in general mostly 'satisfied' with living in housing estates, as positive assessment prevails in this respect.

The effort to understand the above facts can be based on various assumptions, the particular reasons behind the attitudes can vary considerably in different individuals, and this particular issue is clearly multidimensional. 'Objectively', moving to flats in housing estates was frequently perceived as a solution to having one's own place to stay (especially for young families). This reason has remained relevant to this day, as housing estate flats still have a relatively good 'benefit-cost' ratio. Likewise, as pointed out by Kallabová (2004), moving to housing estate flats meant raising one's housing standard and comfort of living, especially in the past. The 'subjective' reasons behind positive attitudes toward housing estates are probably caused by processes relating to the adaptation to specific environments, to the creation of local identity and 'local patriotism' (Andráško et al. 2013). The influence of these factors certainly depends heavily on the stage of life or specific situation o $f$ the individuals - for a young pair, living in a panel house flat could represent happiness of having their own space to create a common household; children living in housing estates spent their childhood there, in many cases including their first steps and experiences of the surrounding world, first stages of establishing social relationships outside their families, and so on (these aspects were accurately described by Barvíková 2010, using the Jižní Město housing estate in Prague as an example). The above groups (young people, children) can be viewed as typical of the early, 'initiation' stages of housing estates - the demographic structure in housing estates was usually deformed, comprising two generations (young parents and their children) - and despite certain eroding processes, this structure still tends to endure (see, for instance, Bleha \& Popjaková 2007).

Another example of the focus on the research of the perception of housing estates is represented by the 'spatial preference' studies. Typical examples include studies of perception of the housing estate position within the city in terms of its 'positively' or 'negatively' perceived districts or city wards (e.g. Steinführerová 2003; Andráško et al. 2013). These are compared with the preference of other urban districts of different types. These types of studies are beneficial, as they (simply put) allow the comparison of evaluative attitudes toward housing estates held by people who do not live there as opposed to the attitudes of the residents - Barvíková (2010: 61) uses the terms 'outsiders' and 'insiders', while Andráško et al. 2013 speak about the 'external' and 'internal' image of housing estates. 
The results of these investigations point out, in particular, that housing estates are perceived worse from the 'outside' than from the 'inside'. But this is not universally true. Andráško et al. (2013) pointed out that the Lesná housing estate in Brno has maintained a long-term good reputation, and, moreover, the residents of Brno regard it as the best district for living in terms of the whole city. On the other hand, the Bohunice housing estate had the worst 'external' image among housing estates in Brno. However, both housing estates were evaluated almost identically in terms of the 'internal' image, i.e. according to the opinions of their residents, with a substantial inclination toward positive evaluation and high ratio of preference for the 'home' housing estates as the best district for living in the city.

As regards the 'target groups', the investigations do not focus solely on the perception of housing estates by their residents, viewed as the general public or 'laymen'. Some studies also present the opinions and attitudes of so-called 'experts' - scientists, representatives of local governments and others. For instance, Sýkora and Hrychová (2002: 19) attempted to "obtain the individual, subjective insight of selected experts who work in miscellaneous city development areas". This investigation focused on a wider approach to changes in the spatial structure of Prague, but (understandably) a significant part of acquired information involved housing estates. The opinions toward the present condition and future development of housing estates were frequently sceptical and even negative. This corresponds to the opinions of experts stated in various studies, and shows that there are substantial differences between how housing estates are perceived by the experts and the residents. Maier (2003: 657) states that the differences are sometimes striking, while noting in relation to revitalisation measures, that "overcoming the shortcomings identified by the housing estate residents would be substantially easier than correcting the problems described by the experts".
People do not represent an internally homogenous 'group of observations' there are many differences among them, leading (potentially) to different manners of perception of the housing estate environment. This fact is frequently 'omitted' - the investigation results are usually generalised and fail to pay sufficient attention to many aspects of the people (like age, gender, stage of life and others) and their relevance to the perception of the environment. This is aptly depicted by Barvíková (2010). Based on interviews with people who grew up in the housing estate environment, the author points out 'changes' in their perception of this environment in relation to various stages in their life - they perceived housing estates differently as children, adolescents and adults. The perception of life in housing estates by 'senior citizens' was addressed by Temelová et al. (2010) and Temelová and Slezáková (2014). In terms of the principal results, these publications do not contradict the above mentioned studies of satisfaction (it must be pointed out here that elderly people constitute a significant part of residents in many contemporary housing estates). For instance, research conducted at the Háje housing estate in Prague showed that the "transformation period and market environment positively influenced the development of civic amenities in housing estates, making essential goods easily available to senior citizens. A great advantage of housing estates in comparison to inner city districts is represented by the nearness of nature and green spaces, where the majority of seniors spend their free time" (Temelová et al. 2010: 110). The inclusion of two more housing estates in Prague - Invalidovna and Nové Butovice - had no influence on the results, and Temelová and Slezáková (2014: 90) conclude their article by stating that "(...)our study suggests that the majority of elderly people are satisfied with their present residences and do not intend to move away". The opposite side of the age spectrum of housing estate residents was addressed by Kallabová (2004), who pointed out various ways of 
perception and representation of the housing estate environment in children's drawings.

The brief overview of articles presented above suggests that in terms of spatial focus, the investigation into the perception of the Czech housing estates mostly concentrates on the territory of large cities, primarily Prague and Brno, the largest cities in the Czech Republic. This fact is understandable: on one hand, large housing estate complexes, often well-known to residents of other parts of the country (for instance, housing estates of Lesná in Brno and Jižní Město in Prague are frequently mentioned in the media), are located in the territory of these two cities, and on the other hand, important research institutions are based in Brno and Prague, which is essential given the need for the researcher's frequent and intensive contact with the territory being studied. However, this does not mean that the investigation into the perception of housing estates is limited exclusively to these two cities. Vaníček and Buzu (2003), for example, examined and compared the perception and assessment of living in selected housing estates in Tábor and Sezimovo Ústí. Utilising findings of her own field research, Kallabová (2004) mentions in her study some aspects of perception of the housing estate environment in Ostrava. Temelová et al. (2011) pointed out the connection between the perception of the environment, its image and the development of its social and physical structure using the Kročehlavy housing estate in Kladno as an example. All the above studies are beneficial in contributing to the greater knowledge of the diversity of Czech housing estates. In principle, they do not contradict the common features of most housing estates, as introduced above, but they reveal that each housing estate has its own specific features, apparent not only in comparison with other housing estates, but also within its own internal structure.

Finally, let us look at the perception of the processes of regeneration and humanisation of the housing estate environment. It must be stated, unfortunately, that available information is scarce. The evaluations and opinions concerning the above mentioned, extremely relevant conversions of housing estates have mostly occurred only as an implicit part of the research projects and their results. Certain references can be found in the publications of Maier (2003), Kallabová (2004), Temelová and Slezáková (2014) and other authors. Interviews conducted by Barvíková (2010) suggest satisfaction with the construction and improvements of children's playgrounds. Further information is available in the publication of Andráško et al. (2013). The authors point out, for instance, the improvement of the overall image of Bohunice housing estates in Brno in the context of the redevelopment of public areas and house facades. As regards the visual side, brighter and more optimistic colours that replaced the 'panel grey' played an important role. But not all conversions applied to the environment and its components are necessarily perceived as positive ones. For instance, a large number of 'new' balconies were constructed in Lesná housing estate in Brno - and although they increased the comfort of living to a certain extent and many residents welcomed this project, there were also numerous negative reactions (primarily by elderly residents).

The previous text attempted to briefly discuss the issues of perception of housing estates and to call attention to certain studies that can be viewed as relevant in this respect (focusing on the Czech Republic). We did not intend to provide a 'comprehensive' overview, but rather direct attention to the main conclusions and knowledge currently available. This outline can also serve as a starting point for further investigations - it is evident that many questions remain unanswered, that our understanding of the processes that form the current housing estates is still limited to a great extent, and that there is a 'practical' importance to paying attention to these matters. Likewise, the ongoing measures, which should lead to the regeneration and humanisation of the housing estate environment, will need to be 
evaluated later after a sufficient period of time. A large quantity of 'unused space' concerns methodological and methodical aspects of research. The perception of housing estates does not mean solely the expression of evaluative or preferential opinions; its context is much wider, one that connects a number of content aspects, relations and meanings (for a wider discussion, see, for instance, Frantál et al. 2012; Mulíček et al. 2013) and is tied to the forming and construction of the overall image of the environment (Andráško et al. 2011).

\section{Conclusions}

The construction of housing estates during the period of socialism was conceptually based on the need for the socialist industrialisation of countries in the region of CEE and on the post-war development of cities (Hamilton et al. 2005; Würth \& Lintz 2006; Domański 2009, and others). Housing estates played an important part in satisfying the housing needs of the growing urban population and changing the sanitary and social parameters of housing. The purpose of their construction was to ensure sufficient housing capacity for a large number of new inhabitants in a short time. Such motivation can definitely be described as 'quantitative'. Large-panel system technology was the most common in construction of housing estates in most of the CEE countries during the peak period of socialism. Twenty-five years since the fall of the Iron Curtain, these housing estates still occupy an important place in the system of urban housing environment in all post-socialist countries of CEE (Temelová et al. 2011; Szafrańska 2013). Their function has not changed in the long run, however, there has been a significant shift in the living in housing estates in terms of lower emphasis on quantitative aspect of housing (which can be documented by a gradual reduction or even complete cessation of this type of housing construction) and increased emphasis on qualitative aspect of housing which includes the effort to improve housing estate environment and houses themselves. In this respect we can speak about 'qualitative' motivation.

While the quality of the original buildings was unsatisfactory as regards both the technical and urban aspect, a logical question arose as to whether or not it would be efficient to demolish these housing estates or at least leave the buildings to 'expire' and create better living conditions by instead investing into the construction of new, quality residential areas (Wassenberg 2004; Lux et al. 2005). However, such solutions proved to be infeasible in reality (save for some East German cities) due to excessive financial costs as well as with respect to the argument that there was no free housing capacity in most countries (if for a short transient period) for mass relocation of housing estate residents. Ultimately, it was decided that the best way was the physical regeneration of apartment houses, providing a substantial increase of their service life, and overall humanisation of housing estates, comprising a wide spectrum of activities (see Fig. 2) that lead to the comprehensive improvement of conditions at these housing complexes. The preservation of flats in the regenerated panel houses can be viewed as a reserve for cheaper housing, while more demanding residents can move to newly constructed houses within the inner urban structure or to rural areas. Even though a large-scale 'exodus' of people from the housing estates, with the associated social decline, has not been reported in the region so far (again save for some East German cities - Liebmann \& Rietdorf 2001; Rietdorf et al. 2001), it can be pointed out that at least in the case of the suburbanisation of larger cities, a partial loss of social cohesion in the post-socialist housing estates is evident (Tanninen 1994; Kallabová 2004; Sunega \& Kostelecký 2007; Špaček 2012; Warchalska-Troll 2012).

Our article also showed that the actual process of the humanisation of housing estates in CEE cities has focused mainly on the rectification of physical condition of poor-quality buildings and the revitalisation of untended 
public areas. Funds expended for these efforts come from various sources, most commonly from local or national governments that establish special-purpose subsidy funds and titles. There are also considerable international funds involved, either in the form of Structural Funds for the EU countries, or through the international development assistance programmes (especially for countries outside the EU). As Andráško et al. (2013) point out, it is necessary to perceive the problem of housing estates and the quality of life of their inhabitants in a complex way - individual environment spheres and components of life in housing estates (social, physical) are interconnected by mutual links. Therefore, the question of housing estate administration comes into focus and the most important role in this respect is played by local government.

It is also necessary to emphasize the importance of participation of local inhabitants in the decision-making processes. The involvement of local residents has also proven important, as they can influence, at least partially, the new appearance of their place of living. The extent of involvement is then reflected in the perception of the humanisation processes. The greater the residents' involvement in the future appearance of the location (flat/house/housing estates), the better is their satisfaction with the result. The opportunity to 'get involved' in the process of humanisation increases the connection between local residents and their living environment, forming their own identity to a certain extent. This is documented in researches conducted in the environment of selected post-socialist housing estates (Fňukal \& Szczyrba 2004; Sunega \& Lux 2004; Musterd \& van Kempen et al. 2005; Kallabová \& Bílek 2006; Hercik et al. 2012; Kovács \& Herfert 2012; Špaček 2012; Warchalska-Troll 2012; Andráško et al., 2013). Thus, the former socialist housing estates can gain much more than just the rectification of technical and planning shortcomings from the period dating back 25 years.
Nowadays the problem of humanization of post-socialist housing estates is one of relatively frequent research topics. This is manifested by some international projects dealing with housing estates in former socialist CEE countries. One of them was the RESTATE project (Restructuring Large Housing Estates in European Cities: Good Practices and New Visions for Sustainable Neighbourhoods and Cities) which involved empirical research focused on large housing estates in cities of ten European countries (Dekker \& van Kempen 2004). In the countries of Visegrad Group another project called HEAS (Housing Estates After Socialism) was implemented which was focused on sharing data and experiences with post-socialist housing estates in selected towns of $\mathrm{V} 4$ countries. A whole range of case studies emerged within these projects from selected cities such as Černič Mali et al. 2003; Erdösi et al. 2003; Węcławowicz et al. 2003; Musterd \& van Kempen et al. 2005; van Kempen et al. 2005; and others (all as RESTATE project results) or Andráško et al. 2013; Eröss 2013; Szabó 2013; Šuška \& Stasíková 2013; Warchalska-Troll 2013 (all as HEAS project results).

\section{Acknowledgements}

This contribution was supported by the Internal Grant Agency of Palacký University Olomouc under project grant Geographical structures and interactions: analysis and modelling of the organization of space (IGA PrF_2015_006) and internal project of Faculty of Economics and Administration, Masaryk University (MUNI/A/1197/2014).

\section{Editors' note:}

Unless otherwise stated, the sources of tables and figures are the authors', on the basis of their own research. 


\section{References}

Abramson D.B., 1992. Participation in post-socialist housing. Boston: Massachusetts Institute of Technology [Master thesis].

ANDRÁŠKO I., 2013. Quality of life: An introduction to the concept. Brno: Masarykova univerzita.

AndrÁšKo I., Lesová P., Kunc J., TONEV P., 2013. Perception of quality of life in Brno Housing Estates. Hungarian Geographical Bulletin, vol. 62, no. 1, pp. 99-109.

ANDRÁŠKO I., SOUKALOVÁ L., ŠUŠKA P., 2011. Obraz miesta - realitný imidž verzus reálny stav [in:] I. Andráško, V. Ira, E. Kallabová (eds.), Časovo-priestorové aspekty regionálnych štruktúr ČR a SR, Bratislava: Geografický ústav SAV, pp. 5-11.

AUGUR Consulting, 2011. Závěrečná zpráva: Dlouhodobý výzkum brněnských sídlišt' 2011. Brno: AUGUR Consulting.

Barvíková J., 2010. Jak se žije na Jižním Městě z pohledu "Husákových děti". Sociální studia, vol. 7, no. 3, pp. 59-78.

BEREY K., 1997. Utopia and reality - the Examples of two housing estates in Budapest. Münchener geographische Hefte, no. 76, pp. 203-215.

Bleha B., Popjaková D., 2007. Migrácia ako dôležitý determinant budúceho vývoja na lokálnej úrovni - príklad Petržalky. Geografický časopis, vol. 59, no. 3, pp. 265-291.

Coudroy de Lille L., 2001. Jak dalece można porównywać miasta europejskie? Refleksje nad procesami i pojęciami na przykładzie osiedli meiszkaniowych we Francji i w Polsce [in:] I. Jażdżewska (red.), Miasto postsocjalistyczne - organizacja przestrzeni miejskiej jej przemian, XII. Konwersatorium wiedzy o mieście, Łodź: Uniwersytet Łódzki, pp. 99-112.

CSABA T., 2006. How we really live in panel blocks: Case study on the conditions and potentials of large housing estates in Budapestfor sustainable development. Den Haag / Budapest, http://www.urbanisztika.bme.hu/segedlet/ angol/panelstudy_cst.pdf [25 August 2015].

Černič Mali B., Sendi R., Boškič R., Filipovič M., GORŠIČ N., ZAVIRŠEK HuDNIK D., 2003. Large housing estates in Slovenia: Overview of developments and problems in Ljubljana and Koper. RESTATE report 2g, Utrecht: Urban and Region- al Research Centre Utrecht. Faculty of Geosciences. Utrecht University.

CZSO, 2014. Czech Statistical Office, http://www. czso.cz/ [14 November 2014].

DANIELOVÁ K., 2012. Vybrané transformačné procesy a ich prejav $v$ priestorovej štruktúre města Trenčín v období 1989-2009 [in:] V. Klímová, V. Žítek (eds.), XV. mezinárodní kolokvium o regionálních vědách, Brno: Masaryk University, pp. 213-222.

Dekker K., van Kempen R., 2004. Large housing estates in Europe: Current situation and developments. Tijdschrift voor Economische en Sociale Geografie, vol. 95, no. 5, pp. 570-577.

Dimitrovska Andrews K., Sendi R., 2001. Large housing estates in Slovenia: A framework for renewal. International Journal of Housing Policy, vol. 1, no. 2, pp. 233-255.

Divina M., 2010. Podoby brněnských panelových sídlišt'. Brno: Masarykova univerzita [Thesis].

DOMAŃSKI B., 2009. Rewitalizacja terenów poprzemysłowych - specyfika wyzwań i instrumentów [in:] W. Jarczewski (ed.), Przestrzenne aspekty rewitalizacji - śródmieścia, blokowiska, tereny poprzemysłowe, pokolejowe i powojskowe, Tom 4, Kraków: Instytut Rozwoju Miast, pp. 125-138.

Erdösı S., Geröházi E., Teller N., Tosics I., Ekés A., Dancza I., Popovics L., SzemzÖ H., 2003. Large housing estates in Hungary: Overview of developments and problems in Budapest and Nyíregyháza. RESTATE report 2c, Utrecht: Urban and Regional Research Centre Utrecht. Faculty of Geosciences. Utrecht University.

ERÖss A., 2013. Past and present of large housing estates in Visegrad countries and Armenia. Hungarian Geographical Bulletin, vol. 62, no. 1, pp. 77-82.

Ferenčuhová S., Jayne M., 2013. Zvyknút' si na Petržalku: každodenný život, bežná spotreba a vztah k socialistickému sídlisku. Český lid, vol. 100, no. 3, pp. 303-318.

FetTers T., 2002. The Lustron home: The history of a postwar prefabricated housing experiment. North Carolina: British Library.

FŇUKAL M., SZCZYrBa Z., 2004. Bydlení a životní prostor ve městech - sociogeografický výzkum katedry geografie PřF Univerzity Palackého v Olomouci [in:] Fňukal M., Szczyrba Z. (eds.), Sborník referátů s konference Bydlení - nové 
formy a dimenze, Olomouc: Palacký University in Olomouc, pp. 79-86.

Frantál B., Klapka P., Siwek T., 2012. Lidské chování v prostoru a čase: teoreticko-metodologická východiska. Sociologický časopis, vol. 48, no. 5, pp. 833-857.

Halás M., Džupinová E., 2007. Vývoj a priestorové rozloženie bytového fondu. Urbanismus a územní rozvoj, vol. 10, no. 2, pp. 27-35.

HALL T., VIDÉN S., 2005. The million homes programme: A review of the great Swedish planning project. Planning Perspectives, vol. 20, no. 3, pp. 301-328.

Hamilton I., Dimitrovska-Andrews K., PilcherMilanovic N., 2005. Transformation of cities in Central and Eastern Europe: Towards globalization. New York: United Nations University Press.

HerCIK J., TOuŠEK V., ŠERÝ O., 2012. La conversione dei siti militari nella Repubblica Ceca: $i$ casi di Hodonín e Uherské. Territorio, vol. 62, no. 9, pp. 43-46.

Herfert G., Neugebauer C.S., Smigiel Ch., 2013. Living in residential satisfaction? Insights from large-scale housing estates in Central and Eastern Europe. Tijdschrift voor Economische en Sociale Geografie, vol. 104, no. 1, pp. 57-74.

HrưZA J., 1996. Vývoj urbanismu II. Prague: Czech Technical University in Prague.

Jarosz D., 2010. Mieszkanie się należy. Studium z peerelowskich praktyk społecznych. Warszawa: Aspra.

JORDAN P., 2010. Decentralisation processes in Central and Southeast European transformation countries: A comparative survey. Acta Universitatis Palackianae Olomucensis - Geographica, vol. 41, no. 1, pp. 15-34.

Kabisch S., Grossmann K., 2013. Challenges for large housing estates in light of population decline and ageing: Results of a long-term survey in East Germany. Habitat International, 39, pp. 232-239.

Kallabová E., 2002. Trends in the issue of prefab housing estates with emphasis on their recovery (with examples from the Czech Republic). Moravian Geographical Reports, vol. 10, no. 1, pp. 26-31.

Kallabová E., 2004. Sociálně geografické souvislosti panelových sídlišt' a problémy jejich vývoje $\checkmark$ České republice. Brno: Masaryk University [Thesis].

Kallabová E., Bílek J., 2006. The historical background and current situation of mass (Industrial) forms of housing in the Ostrava Region (Czech Republic). Moravian Geographical Reports, vol. 14, no. 2, pp. 27-42.

Kovács Z., Herfert G., 2012. Development pathways of large housing estates in post-socialist cities: An international comparison. Housing Studies, vol. 27, no. 3, pp. 324-342.

LieBMANN H., Rietdorf W., 2001. Großsiedlungen in Ostmitteleuropa zwischen gestern und morgen. Europa Regional, vol. 9, no. 2, pp. 78-88.

lux M., Sunega P., Kostelecký T., Čermák D., MontaG J., 2005. Standardy bydlení 2004/ 2005: Financování bydlení a regenerace sídlišt. Prague: Institute of Sociology of the Academy of Sciences of the Czech Republic.

Maier K., 2003. Sídliště: problém a multikriteriální analýza jako součást prípravy k jeho řešení Housing estates: The problem and the preparation to tackle it. Sociologický časopis/Czech Sociological Review, vol. 39, no. 5, pp. 653-666.

MaIeR K., 2005. Czech housing estates: Recent changes and new challenges. Geographia Polonica, vol. 78, no. 1, pp. 39-51.

Matlovič R., Sedláková A., 2007. Transformation processes of the urban space in postcommunist cities [in:] M. Malikowski, S. Solecki (eds.), Przemiany przestrzenne $w$ dużych miastach Polski i Europy Środkowo-Wschodniej, Kraków: Nomos, pp. 32-46.

Mulíček O., Osman R., Seidenglanz D., 2013. Imaginace a reprezentace prostoru $v$ každodenní zkušenosti. Sociologický časopis, vol. 49, no. 5, pp. 781-810.

MRD, 2014. Ministry of Regional Development of the Czech Republic, http://www.mmr.cz/ [1 December 2014].

Murie A., Knorr-Siedow T., van Kempen R., 2003. Large housing estates in Europe: General developments and theoretical backgrounds. RESTATE report 1, Utrecht: Urban and Regional Research Centre Utrecht. Faculty of Geosciences. Utrecht University.

MusIL J., 1985. Lidé a sídliště. Prague: Svoboda.

Musil J., 2002. Urbanizace českých zemí a socialismus [in:] P. Horská, E. Maur, J. Musil (eds.), 
Zrod velkoměsta. Urbanizace českých zemí a Evropa. Prague: Paseka, 237-297.

Musterd S., van Kempen R., 2005. Large housing estates in European cities: Opinions of residents on recent developments. RESTATE report 4k, Utrecht: Urban and Regional Research Centre Utrecht, Faculty of Geosciences, Utrecht University.

Müller E. (ed.), 1997. Großwohnsiedlungen in europäischen Städten. Beiträge zur Regionalen Geographie, no. 45. Leipzig: Institut für Länderkunde.

PÁsztor G., Péter L., 2009. Urban housing problem in Romania: The legacy of communist block of flats. Studia universitatis Babes-Bolyai, Sociologia, no. 1, pp. 79-100.

Rietdorf W., Liebmann H., Haller, C., 2001. Schrumpfende städte - Verlassene grosssiedlungen? Stadtstrukturelle bedeutung und probleme von grosswohnsiedlungen. DISP, vol. 146, no. 3, pp. 4-12.

RoJík V., 1974. Panelové objekty. Prague: State Publishing House of Technical Literature.

Rowlands R., Musterd S., van Kempen R. (eds.), 2009. Mass housing in Europe: Multiple faces of development, change and response. New York: Palgrave Macmillan.

Sargsyan T., 2013. Residential environmental conditions on housing estates in Yerevan. Hungarian Geographical Bulletin, vol. 62, no. 1, pp. 121-130.

SChÜTte I., KüHN M., 2004. Lebensqualität in Klein und Mittelstädten - ein Berichtssystem im Städtekranz des Landes Brandenburg. Mitteilungen: Problemorientierte Regionale Berichtssysteme, 1, pp. 35-50.

Stanilov K., 2007. The post-socialist city. Urban form and space transformation in Central and Eastern Europe after socialism. Dordrecht: Springer.

StASíKOVÁ L., 2013. Genuis loci vo vztáahu k strachu zo zločinnosti na príklade postsocialistického. Geografický časopis, vol. 65, no. 1, pp. 83-101.

SteinfüHREROVÁ A., 2003. Sociálně prostorové struktury mezi setrvalostí a změnou. Historický a současný pohled na Brno. Sociologický časopis, vol. 39, no. 2, pp. 169-192.

StrYJAKIEWICZ T., 2009. The old and new in the geographical pattern of the Polish transition. Acta
Universitatis Palackianae Olomucensis - Geographica, vol. 40, no. 1, pp. 5-24.

Sunega P., Kostelecký T., 2007. Prostředí sídlišt' $\checkmark$ ČR a v zahraničí: vybrané aspekty sociálni udržitelnosti. Proceedings from URBES 2007 Conference, http://www.disparity.cz/data/ USR_048_DEFAULT/urbes2007_sunega_kostelecky.pdf [20 August 2015].

Sunega P., Lux M., 2004. Participace nájemníků a sociální aspekty regenerace panelových sídlišt jako jedna z podmínek trvale udržitelného rozvoje. Urbanismus a územní rozvoj, vol. 7, no. 3, pp. 5-9.

SÝKORA L., 2009. Post-socialist cities [in:] R. Kitchin, N. Thrift (eds.), International Encyclopedia of Human Geography, Amsterdam: Elsevier, pp. 387-395.

SÝKora L., Hrychová H., 2002. Percepce a hodnocení proměn v prostorové struktuře Prahy. Urbanismus a územní rozvoj, vol. 5, no. 1, pp. 19-23.

SzABÓ B., 2013. Ten years of housing estate rehabilitation in Budapest. Hungarian Geographical Bulletin, vol. 62, no. 1, pp. 113-120.

SzAfrańsKa E., 2013. Large housing estates in post-socialist Poland as a housing policy challenge. European Spatial Research and Policy, vol. 20, no. 1, pp. 119-129.

SZAFrAŃSKA E., 2014. Transformations of large housing estates in post-socialist city: The case of Łódź, Poland. Geographia Polonica, vol. 87, no. 1, pp. 77-93.

SzELENYI I., 1996. Cities under socialism - and after [in:] A. Gregory, M. Harloe, I. Szelenyi (eds.), Cities after socialism: Urban and regional change and conflict in post-socialist societies. Oxford: Blackwell Publisher, pp. 286-317.

ŠPAČEK O., 2012. Česká panelová sídliště: faktory stability a budoucího vývoje. Sociologický časopis, vol. 48, no. 5, pp. 965-988.

ŠuŠKA P., StASÍKOVÁ L., 2013. Transformation of the built environment in Petržalka pre-fabricated housing estate. Hungarian Geographical Bulletin, vol. 62, no. 1, pp. 83-89.

TANNINEN T., 1994. Large-scale housing estates as a societal task in Eastern Germany [in:] T. Tanninen, I. Ambrose, O. Siksiö, (eds.), Housing in transition. East-West dialogue on the new roles of actors in changing housing policies, Dessau: Bauhaus Dessau, pp. 157-174. 
Temelová J., Dvořáková N., Slezáková A., 2010. Rezidenční spokojenost seniorů v proměňujicich se čtvrtích Prahy. Sociální studia, vol. 7, no. 3, pp. 95-113.

Temelová J., Novák J., OuŘedníček M., Puldová P., 2011. Housing estates in the Czech Republic after socialism: Various trajectories and inner differentiation. Urban Studies, vol. 48, no. 9, pp. 1811-1834.

Temelová J., Slezáková A., 2014. The changing environment and neighbourhood satisfaction in socialist high-rise panel housing estates: The time-comparative perceptions of elderly residents in Prague. Cities, vol. 37, pp. 82-91.

TRÓCSÁNYI A., Orbán K., 2012. Hungarian challenges of housing block regeneration: A case study of Uránváros, city of Pécs. Revija za geografijo - Journal for Geography, vol. 7, no. 2, pp. 51-68.

van Kempen R., Dekker K., Hall S., Tosics I. (eds.), 2005. Restructuring large housing estates in Europe. Bristol: The Policy Press.

VANí̌̌EK J., BuZu D., 2003. Jak ovlivñuje charakter zástavby spokojenost lidís bydlením. Urbanismus a územní rozvoj, vol. 6, no. 1, pp. 36-40.

Warchalska-Troll A., 2012. How to measure susceptibility to degradation in large post-socialist housing estates? Prace Geograficzne, 130, Kraków: Instytut Geografii i Gospodarki Przestrzennej UJ, pp. 55-71.
Warchalska-Troll A., 2013. Progress of rehabilitation of large housing estates in Katowice (Poland). Hungarian Geographical Bulletin, vol. 62, no. 1, pp. 102-112.

WASSENBERG F., 2004. Large social housing estates: From stigma to demolition? Journal of Housing and the Built Environment, vol. 19, no. 3, pp. 223-232.

WęcŁawowicz G., KozŁowski S., Bajek R., 2003. Large housing estates in Poland: Overview of developments and problems in Warsaw. RESTATE report 2f, Utrecht: Urban and Regional Research Centre Utrecht. Faculty of Geosciences. Utrecht University.

WiEGANDT C.C., 2000. Urban development in Germany - perspectives for the future. GeoJournal, vol. 50, no. 1, pp. 51-55.

WIEST K., 2011. Large-scale housing estates in Central and East European cities: Between residential preferences and local housing market differences. Housing, Theory and Society, vol. 28, no. 4, pp. 410-431.

ZADRAŽILOVÁ L., 2013. Když se utopie stane skutečností. Prague: Arbor vitae.
(C) Petr Šimáček et al.
Article first received • December 2014 Article accepted • September 2015 